12th LUMEN International Scientific Conference Rethinking Social Action. Core Values in Practice | RSACVP 2019 | 15-17 May 2019 | lasi - Romania

\title{
Museum Communication and Entrepreneurial Thinking
}

\author{
Cristina Claudia POPESCU
}

https://doi.org/10.18662/lumproc. 173

How to cite: Popescu, C.C. (2019). Museum Communication and Entrepreneurial Thinking. In C. Ignatescu (ed.), 12th LUMEN International Scientific Conference Rethinking Social Action. Core Values in Practice, 15-17 May 2019, Iasi - Romania (pp. 263-273). Iasi, Romania: LUMEN

Proceedings. https://doi.org/10.18662/lumproc.173 


\title{
Museum Communication and Entrepreneurial Thinking
}

\section{Cristina Claudia POPESCU1}

\begin{abstract}
Museums need to become competitive and to maximize their limited resources. To do so they need belp from their visitors and from other institutions, they need to exchange and remix information in order to create relevance and innovation, and also they need money for various investments. Updating museums is often thought of in a commercial manner, inspired by commercial organizations that use marketing and entertainment in order to increase their profit or competitiveness. This entrepreneurial thinking can make museums to be self-sufficient and to avoid collaboration. The collaboration between museums and other institutions (commercial, cultural, nongovernment, publishing) or with the general public is thus neglected and also the need for a personal relation and a personalized experience for the visitor. The relationship approach is connected with the notion of reciprocation which, according with sociologists, is central to the wellbeing of any society. Even though reciprocation isn't always equal or fair, both economic entrepreneurs and members of the publishing industry have social preoccupations, tied to the idea of awareness. Museums and other cultural institutions, due to bureaucracy, are insufficiently interested in the idea of reciprocity witch, in museum studies terms, could also be called participation and it is associated with the idea of awareness.

Museum communication can be seen as a kaleidoscope combining four discursive approaches: promotion (marketing), awareness (NGO-s), information (journalism), education (more or less institutionalized and open to the new).
\end{abstract}

Keywords: museum communication; awareness; participation; relationship marketing; authentic experience.

\footnotetext{
1 Popescu Cristina Claudia is curator of the Exhibition and Documentary Centre of the University of Architecture and Urbanism Ion Mincu in Bucharest and PhD student in Arts at the National Arts University Bucharest, Romania, claucris popescu@yahoo.com, 0726979532 .
} 


\section{Introduction}

There are many analyzes that emphasize the need to modernize Romanian museums (The Cultural Consumption Barometer from 2015 [1], among others). Many such analyzes recall the need for museums to take the role of commercial organizations in order to cope with competition. Including the Culture Minister considered that museums should make a profit. Museums, Culture, and Education are important enough to be subsidized even in countries with more liberal inclinations than Romania. This article aims to analyze the nuances and limits of commercial inspiration in museum communication [2] and to come up with suggestions applicable to Romanian museums.

\section{Theoretical Background}

Museums have to offer something in return for the funds they are given both directly by visitors and indirectly by sponsors (State, other institutions, etc.). There are some possible justifications:

- preserving memory

- creating experiences that are inaccessible elsewhere (through fiction, theatricality, high value collections, authentical objects etc.)

- community projects and proposals (addressed to sponsors for grants).

\section{Argument of the paper}

For all these reasons museums are supposed to care about their visitors not just as clients but as individuals that are best to be approached through Relationship marketing. If we remember that museums first emerged as displays of power and wealth accessible to only a few we come to understand that what they offer is not so much a product as it is an experience and a relationship.[3]

\section{Arguments to support the thesis}

1. As for the first reason (the preservation of memory), this is not only about the preservation of the patrimony but also about its accessibility. Museums offer digitization, documentation. That is informative communication.

Being competitive is sometimes understood by museums as being a reliable source of online (and offline) information. The authority of collections presented in the digital space (knowledge systems supplemented with texts, images and stories) is considered a competitive advantage by 
some authors compared with the informational cacophony surrounding them. [4] Many online resources insist on the credentials and expertise of the organizations involved. The Art Project, European and many other online museums try to create a matrix of trust that frames their online content.[5] The above approach (based on quality products and verified information) ignores the fictional, theatrical tradition of museums.[6] History is not only the objective one but also the experienced one, with all its subjectivity. Authenticity is a romantic theme (which is a component of the modern tourism industry: the 'market of experiences').[7] Also romantic is the concern about the value of art to the detriment of market requirements. [8]

2. As to the second reason (special experiences), we talk about a participation to the experience market. This includes approaches such as accessibility, interpretation of collections.

The market of experiences (which the museums are a part of) is actually a combination of nineteenth-century Romantic myths and twentieth-century consumerist myths.[7] The museums cannot afford to consider as relevant only the Romantic myths, it has to be relevant also for the consumerist ones. And vice versa. Interpreting collections is not just about the objects but also about their consumers. This is where the educational and the promotional communication intertwine.

"There is a shift from the primacy of authentic object" (the object that can be verified empirically), to "the primacy of authentic experience" (an object that brings to light the hidden human potential).[9]

3. With regard to the third reason (community projects) if the main sponsor is the State that allocates funds regardless of the museum offer, then the projects offered will be of some kind, if there are other sponsors (Companies, NGOs, associations, etc.) or the State oversees museum programs and their relevance to the community, then they will take a more political turn. This is where participatory projects based on awareness fit in.

Visitor participation is encouraged by the way objects are curated and narrated as a dialogue about identity, as a way to create awareness. In this vision "museums are not about the interpretation of objects but the means to create public awareness about bigger issues [...] Education and learning is replaced by awareness making. Subject matters that traditionally preoccupy academia and museums are replaced by topics that should concern political organizations and the news media."[10]

\section{Arguments to argue the thesis}

After listening to Nina Simon's speech at the Museums Meet Museums Conference in Bucharest [11] I thought about ways of 
implementing a participative vision in Romanian museums. At first it seemed that they aren't prepared for such a leap: they are too bureaucratically tangled to take such a risk. The attempt of museums (such as those from Romania and other ex-communist countries) to enact new museum theory could affect their economic survival. As Margaret Lindauer noticed: "It is a daunting task to produce exhibits that encourage informed debate, grounded in explorations of social relations, inscribed in representations of multi-faceted social, cultural, and aesthetic histories." Since museums have to satisfy market needs they could wait for the market to change or they could encourage the creation of new needs. One approach could be that of creating critical museum visitors witch, in time, could become agents of change.[12] Another approach (that of Nina Simon) is a more active one: rather than wait for visitor recommendations after an exhibition, why not involve visitors in their actual making?

The relationship approach is connected with the notion of reciprocation which, according with sociologists, is central to the well-being of any society.[13] But the quality and creativity of cultural content may not be enough to ensure museum success. The monetary rewards of popular culture markets are concentrated in the hands of a few. Their success is not defined by the quality of their performances, but by their quick financial success [14], through the use of sensationalism, violence and other devices. A degree of popularity becomes afterwards a credential as one cultural product can be shared with friends and significant others. Other than the search for strong experiences the audience feels also the need to reciprocate the attention they feel it has been given to them. These findings are to a certain degree also true for museums and exhibitions. People like to share things, they also like a new experience and also they need to reciprocate the attention they feel it has been given. Museums are getting closer to popular culture markets in their effort to become relevant for their communities, thus their need to be controversial but also attentive and to encourage the sharing of experiences.

\section{Dismantling the arguments against}

Sometimes, entrepreneurial thinking can make museums to be selfsufficient and to avoid collaboration.[15] The collaboration between museums and other institutions (commercial, cultural, nongovernment, publishing) or with the general public is thus neglected.

The core of the marketing concept is "market (or customer) orientation". Museums' efforts to attract a larger audience to already created products (without changing actual performances or exhibitions) could easily 
be criticized. On one hand museums studies literature considers that museums can offer different experiences for different types of visitors. On the other hand museum marketing writings consider that museums have two different aims - to fulfill artistic vision and to satisfy market needs - and the job of arts marketers is to seek a "reconciliation" or "balance" between them.[16] In terms of museum studies there is a need to balance a objectoriented approach and a user oriented approach. So exhibitions and events aren't only about objects and the experiences offered could be as diverse as needed. Nina Simon [17] compares museums with a French restaurant, where everyone can find a dish they like. The offer has to be informed by the tastes of the visitors.

The interaction with museum services and products is often thought of in a commercial manner, inspired by commercial organizations that use marketing and entertainment in order to increase their profit or competitiveness. Museums aren't only about satisfying demands they can also encourage the creation of new demands, new tastes and experiences. For there is a type of public that is eager for new things and it seldom visits museums. In order to create new tastes and experiences the competitive approach (copyright protection, the creation of profit) is not always beneficial. The "competition between rival firms doesn't often lead to useful new products".[18] Rather it is open collaborative networks, uninterested in profit, inviting for both hobbyists and dilettantes that are the birthplace of many innovations. The Internet is a collaborative network and the hobbyists are recognized as one of the museum's publics. Here we have two coordinates of the participative museum approach. An approach the alters fundamentally the way museums "cultivate and promote good ideas".[19] Museums "and other non-market institutions have long suffered from the innovation malaise of top-heavy bureaucracies."[20] By controlling and restricting access to museum-related information, museums prevent the visitors to express themselves and also the creation of now, innovative content. "When you introduce financial rewards into a system, barricades and secrecy emerge, making it harder for the open patterns of innovation to work their magic."[21]

There are several obstacles, listed by Nina Simon [22], that create dissatisfaction to museum visitors: the lack of new content, the lack of relevance of the museum content, the lack of creativity and dialogue inside the museum. All these are addressed by the participatory approach.

Many museums offer a mix of types of learning that are better adapted to market needs: looking and thinking; object-handling; interactive exhibits; demonstration; reconstructions; drama; film. Enabling people to create a personal connection with objects and displays is also used by some 
art museums despite their traditional approach of reverence towards objects rather than to the public. Most art museums limit the mode of learning to a less personal approach, distant from the domestic view of many visitors, based on looking and reading.[23]

In order to encourage innovation, museums may become platforms for conversations. The distinction between the degree of control of an author (or a book) and the collaborative enterprise of an editor (publishing industry) is emphasized by Nicholas Serota (Tate) during a conference held at the London School of Economics (LSE) in July 7, 2009: "The challenge is to what extent do we remain authors, and in what sense do we become publishers providing a platform for international conversations? I am certain that in the next 10 to 15 years, there will be a limited number of people working in galleries, and more effectively working as commissioning editors working on material online".[24] Co-curating and the use of public through crowdsourcing (a form of outsourcing that goes to undifferentiated people rather than a specific group of employees) have been used by museums to learn from those outside the sector.

The fact that museums and curators become publishers also means that they become aware with the "new forms of ownership and understandings of intellectual property associated with the advent of digital media in the publishing sector."[25] Many museums have created copyrightfree online collections. Faced with the impossibility of tracking the misuse of images, many museums and galleries have relinquished copyright except for blatantly commercial purposes.[26]

Collaborative, non-profit-making networks are precisely those that can produce the novelty that museums need. Instead of insisting on the curatorial standards, museums have to regain their relevance and provide new insights without losing contact with the authenticity of objects (the authenticity of the issues discussed is an extension of the authenticity of objects).

The truth is that market-oriented marketing must take into account both the relevance of content and the emotional involvement. It's a different kind of marketing than the product-oriented one. As Nina Simon noticed: "In traditional exhibits and programs, the institution provides [high quality] content for visitors to consume. [...]. In contrast, in participatory projects, the institution [...] serves as a "platform" that connects different users who act as content creators, distributors, consumers, critics, and collaborators."[27] In such a case the museum can no longer guarantee the consistency of visitor experiences since a great deal of noise is involved. But in this approach many new experiences become possible and hopefully they are meaningful for the visitor. 
The interaction between visitor and museum is no longer limited to a clearly defined content that one could archive, rather it includes emotions and personal associations. [28]

Concerns about community involvement in museum activity also have economic implications, including the image development of the organization. Another effect is an increase in public interest for a new actor interested in community issues. [29]

Studies have shown that a dose of noise is required both for learning (by involving emotion and recombination) and for the reuse, enrichment and distribution of museum content through various other media.

Education needs emotion, that is, fiction, and thus education, marketing and technology go hand in hand. But education is not complete without a degree of friction (or redundancy, or noise in terms of communication theory) and for that it needs an authentic object or, at least, an authentic experience.

A group of researchers at Baltimore's Johns Hopkins University investigate if arts integration, an emphasize on the repetition of information in multiple ways, provides the advantage of embedding knowledge in longterm memory. Because all this redundancy may trigger an emotional response and thus encourage the conversion of information to long-term memory.[30]

Whether we are talking about new historicism or new realism, museum studies insist on a necessary degree of relevance to the public and of subjectivity in the content presented by museums. In the search of relevance museums create new interpretive frames: "a shift from belief to a suspension of disbelief; the reemphasis from evidence to the evidenced; and a reblending of the actual real and the ideal real". [31]

Several Romanian museums have faced their difficult heritage in order to come to reconciliation with the past. Both the National Museum of Contemporary Art and the Museum of Romanian Peasant had buildings associated with communism. The Parliament Palace as well as the Communist Party Museum were two symbols of the Romanian Communist regime. Making or re-making museums in these spaces meant rethinking capitalizing the spaces and objects associated with communism. At the Museum of Romanian Peasant, an installation was created with what remained of the former Communist Party Museum objects. At the National Museum of Contemporary Art, propaganda artworks have been exhibited and courageous exhibitions on the relationship between art and power have been curated. Unlike these, most Romanian museums prefer to avoid controversy. One reason would be the traditional preferences of the public but also the many unknowns. Another reason would be the hostility of the 
public towards sensitive subjects such as communism. Museum of Daily Life in Communism (MUVICC), for example, is the successor of a failed project due to controversy. A discussion on the Museums and Museographers Facebook Group confirmed this attitude. It was about an exhibition dedicated to the victims of rape. Many museographers objected that it was not an exhibition and suspected it of inconsistency and sensationalism. From another point of view, this attitude could be considered paternalistic, provided there are some critical visitors to contextualize it. It seems that such visitors exist in the artistic field, which is why some critical elements appeared in the discourse of the National Museum of Contemporary Art and Museum of Romanian Peasant.

Museums cannot be apolitical, they support a certain point of view. And the narrative supported by the Romanian museum is a national one (reminiscent of the national Communism period). "Subjects such as the Romanian Holocaust, the disappearance of Romanian Jewry, the atrocities perpetrated by the Romanian army on the Eastern front during World War Two, the discrimination and slavery of Roma people, the Romanization policies suffered by Hungarian ethnics are among the issues that no museum attempts to exhibit."'[32] This is a management issue but also a sociological one.

According to a research conducted in Romania over a 3-year period (2014-2016), the main role of the museum for the general public $(39 \%)$ and especially for students $(61 \%)$ is to valorize the heritage. $30 \%$ of the general public and $19 \%$ of the students recognize museum's role as an informational channel. Here is something interesting: valorizing the heritage seemed more important to students (familiarized with technology) than just information (about it) while for the general public it is slightly more important to valorize than to inform. Only $9.72 \%$ of the general public and $13.63 \%$ of the students see museums as social mediators.[33] As the cultural landscape evolves and technological knowledge is spreading across the society it is safe to presume that these opinions have changed. It is also interesting to notice that the student's view seems more traditional than that of the general public. The cause of it may me that students are less interested in museums and more aware of their state of affairs while the general public's view is closer to wishful thinking.

\section{Conclusion}

No matter how exotic it may sound, the participative museum, though politically oriented, as any publishing enterprise ought to be, is a market oriented approach that is worth the effort and the risks. As far as 
Romania and other former communist countries are concerned, it is an approach that will take some time for the society and the State to accept.

\section{References}

[1] Becuț A, Croitoru C. Cultural consumption barometer 2015. Preferences, practices, trends. ESSACHESS. Journal for Communication Studies vol. 9, no. 1(17) / 2016: 53-65

[2] Dellaguzzo MR. Marching on together: the future of non-profit museums in a for-profit world, Seton Hall University Dissertations and Theses (ETDs). 2018: 42. [cited 2019 Feb 5]. Available from: http://scholarship.shu.edu/dissertations/2517

[3] Rus A. 'Gift vs. commoditiy' debate revisited. Anthropological Notebooks. 2008; 14 (1): 81-102.

[4] Hazan S. Performing the museum in an age of digital reproduction. Furnace Journal. 2015; 2: 5.

[5] Drotner K, Schrøder KC, editors. Museum communication and social media: The connected museum. New York: Routledge; 2013. pp.42-43.

[6] Drotner K, Schrøder KC, editors. Museum communication and social media: The connected museum. New York: Routledge; 2013. p.44

[7] Harari YN. Sapiens: a brief history of humankind. Toronto: McClelland \& Stewart; 2014. p.86

[8] Lee HK. When arts met marketing: arts marketing theory embedded in Romanticism. International Journal of Cultural Policy. 2005; 11 (3).

[9] Drotner K, Schrøder KC, editors. Museum communication and social media: The connected museum. New York: Routledge; 2013. pp.48-49.

[10] Tondborg B. The dangerous museum. Participatory practices and controversy in museums today. Nordisk Museologi. 2013; 2: 6-7.

[11] Museums Meet Museums international seminar, 15 - 16 sept. 2017, Romanian Pesant Museum, Bucharest.

[12] Lindauer M. The critical museum visitor. In: Marstine J, editor. New museum theory and practice. An introduction. Oxford: Blackwell Publishing; 2006. p.223

[13] Wiseman R. 59 seconds. Think a little, change a lot. New York: Knopf; 2009: 44.

[14] Youngelson-Neal H. Linkages between economics and popular culture. In: Browne RB, Urish B, editors. The dynamics of interconnections in popular culture(s). Cambridge Scholars Publishing; 2014: 67.

[15] Dellaguzzo MR. Marching on together: the future of non-profit museums in a for-profit world. Seton Hall University Dissertations and Theses (ETDs). 
2018: 42. [cited 2019 Feb 5]. Available from:

http://scholarship.shu.edu/dissertations/2517

[16] Lee HK. When arts met marketing: arts marketing theory embedded in Romanticism. International Journal of Cultural Policy. 2005; 11 (3): 4-5, 12, 13.

[17] Ideas expressed by Nina Simon in the „Museums Meet Museums” international seminar, 15 - 16 sept. 2017, Romanian Pesant Museum, Bucharest.

[18] Johnson S. Where good ideas come from: the natural history of innovation. London: Penguin Books Ltd.; 2010: 236.

[19] Johnson S. Where good ideas come from: the natural history of innovation. London: Penguin Books Ltd.; 2010: 243.

[20] Johnson S. Where good ideas come from: the natural history of innovation. London: Penguin Books Ltd.; 2010: 243.

[21] Johnson S. Where good ideas come from: the natural history of innovation. London: Penguin Books Ltd.; 2010: 233.

[22] Simon N. The participatory museum. Santa Cruz: Museum 2.0; 2010: III-IV.

[23] Pearce S, editor. Art in museums. London: Athlone Press; 1995. p.155.

[24] Drotner K, Schrøder KC, editors. Museum communication and social media: The connected museum. New York: Routledge; 2013. p.63.

[25] Vermeeren A, Calvi L, Sabiescu A, editors. Museum experience design. Crowds, ecosystems and novel technologies. New York: Springer International Publishing; 2018. p.326.

[26] Drotner K, Schrøder KC, editors. Museum communication and social media: The connected museum. New York: Routledge; 2013. p.62.

[27] Simon N. The participatory museum. Santa Cruz: Museum 2.0; 2010. p.2.

[28] Giovani Baule. Media-morphosis of a museum. Linea grafica. 2003; 347: 41.

[29] Zbuchea A. Marketingul de relaţii - resursă de dezvoltare a companiei şi de fidelizare a clienților. Calitatea - acces la succes / Quality-Access to Success. 2008; 10: 15.

[30] Drotner K, Schrøder KC, editors. Museum communication and social media: The connected museum. New York: Routledge. 2013. p.79.

[31] Drotner K, Schrøder KC, editors. Museum communication and social media: The connected museum. New York: Routledge. 2013. p. 53.

[32] Bădică S. National museums in Romania. In: Aronsson P, Elgenius G, editors. Building national museums in Europe 1750-2010. Conference proceedings from EuNaMus, European National Museums: Identity politics, the uses of the past and the European citizen, Bologna 28-30 Apr 2011. Linköping University Electronic Press: 720. [cited 2019 Feb 5]. Available from: http://www.ep.liu.se/ecp/064/030/ecp64030.pdf 
[33] Gheorghilaş A, Dumbrăveanu D, Tudoricu A, Crăciun A. The Challenges of the 21st-century museum: dealing with sophisticated visitors in a sophisticated world. International Journal of Scientific Management and Tourism. 2017; 3-4: 64-66. 